\title{
The effectivenes of layanan informasi using contextual teaching and learning (CTL) approach to degree of students pornography trends
}

\author{
Asmidaryani ${ }^{1}$, Firman ${ }^{2}$, Nurhizrah Gistituati ${ }^{3}$ \\ ${ }^{123}$ Universitas Negeri Padang, Padang - Indonesia, (mutiaracin@gmail.com)
}

\begin{abstract}
Nowadays, the trend of student pornography increases every year. An increase in pornographic tendencies is thought to be due to lack of information. Information can be obtained by students through guidance and counseling services in schools. Providing information services will be more effective by using various approaches. This study aims to identify the effectiveness of Layanan Informasi using the CTL approach in reducing the tendency of student pornography. This research used Quasi Experiment design with non equivalent control group design. The research subjects were 21 students in control group and 21 treatment group. The research instrument was student pornography tendency inventory with reliability 0.892 , and data were analyzed using Wilcoxon Signed Ranks Test and Kolmogorov-Smirnov Two Independent Samples. Based on the findings, layanan informasi used CTL approach effective to the reduction of the student pornography tendencies. Counselors are recommended to apply the CTL approach on reducing it.
\end{abstract}

Keywords: pornography, layanan informasi, CTL

\section{Introduction}

Education is an important factor in human life, education can create quality human beings. Education today is more directed at the formation of individuals who have a characteristic personality. One of the goals of education is the formation of self-control in adolescents. . (Desneli, Firman, dan Afrizal Sano, 2016., Nory Natalia, Firman \& Daharnis: 2015)

Adolescence is one of the periods that individuals undergo in the life span. Vocational High School (SMK) students include individuals who are at the stage of adolescent development. the task of development that must be achieved in adolescence that has the desire to be responsible for social behavior. Teens who achieve this developmental task are able to account for their social behavior, able to uphold social values, and behave humanly. Therefore, adolescents will be spared from deviant behavior (pornography). (Imalatul Khaira, Firman, Neviyarni S: 2017)

Pornography is a picture of violent behavior that highlights the body and genitalia. His serene, slovenly, vulgar nature, makes people who see it sexually aroused. (Bungin:2007, Sarwono. 2005) 
The tendency of pornography is caused by a lack of behavioral and behavioral control on every perpetrator, Pornography has a negative impact on the perpetrators, including:

1. Brain damage. For pornography addicts will suffer brain damage, in the middle of the front of the brain will shrink physically, so that there will be a constant change that resulted in the weakening of the control function in the individual, this makes the individual can not control his behavior. Damage to this brain will make feelings not calm, it will create a dependence to pornographic action that gives pleasure to the perpetrators.

2. Hacked free sex and sexual abnormalities, to suffer from various venereal diseases.Pornography is the beginning of free sex,then the deviation of sexual behavior,acts of sexual harassment,until in the end result in the emergence of dangerous diseases such as HIV.

3. Eliminating the importance of marriage.Being forgetful and decreasing performance, as well as worsening social relationships.Individuals who are addicted to pornography will experience a decrease in memory, so that it will automatically decrease its performance, gradually this will disrupt the social relations of others.(Sartika :2016., M Hariyani, M Mudjiran, Y Syukur: 2012, Sri Sunarsih, dkk:2010)

The impact of watching pornographic films on VCDs on adolescent behavior is the occurrence of a poor impersonation. Events in movies motivate and stimulate adolescents to imitate or practice what they see, as a result teenagers become increasingly permissive of existing behaviors and norms. (Rosadi:2001, Katarina Leba,Murni Hermawati Sitanggang:2015).

At this time many teens are trapped in pornographic tendencies, this can be seen in the following KPAI data:

The adolescent boys who were affected by the pornographic books were $59.3 \%$ and the pornographic movies were $48.8 \%$. While in adolescent girls affected by porn book by $28,4 \%$ and in pornographic movies 15.9\%.(Yulianto:2010).

Table 2. Data on Pornography by Students in Padang City (2012)

\begin{tabular}{|c|c|c|c|c|c|c|c|c|c|}
\hline \multirow[t]{3}{*}{$\mathrm{Nu}$. } & \multirow[t]{3}{*}{ Sub Variable } & \multicolumn{8}{|c|}{ Classification } \\
\hline & & \multicolumn{2}{|r|}{ ST } & \multicolumn{2}{|r|}{$T$} & \multicolumn{2}{|c|}{$\mathbf{R}$} & \multicolumn{2}{|c|}{ SR } \\
\hline & & $\mathrm{F}$ & $\%$ & $\mathrm{~F}$ & $\%$ & $\mathrm{~F}$ & $\%$ & $\mathrm{~F}$ & $\%$ \\
\hline 1 & $\begin{array}{l}\text { Intensity of watching and reading } \\
\text { pornography }\end{array}$ & 18 & 22,59 & 52 & 45,98 & 32 & 36,78 & 8 & 5,75 \\
\hline 2 & Sexual behavior deviates from self & 15 & 17,24 & 40 & 47,13 & 25 & 13,79 & 7 & 6,90 \\
\hline 3 & Sexual behavior deviates from others & 29 & 33,33 & 33 & 37,93 & 18 & 20,69 & 7 & 8,05 \\
\hline & Total & 62 & 23,75 & 102 & 39,08 & 75 & 28,74 & 22 & 8,43 \\
\hline
\end{tabular}

Source: ResearchHaryani, dkk.

Based on Table 2, it can be concluded that the intensity of watching and reading pornography of students is in the high category with the percentage of $45.98 \%$, while the self-deviant sexual behavior is also in the high category with the percentage of $47.13 \%$ and deviant sexual behavior towards others 
are in the high category with a percentage of $37.93 \%$. Overall, it can be concluded that the classification of the impact of pornography on students is in the "high" category with the percentage of $39.08 \%$, while the other is in the "very low" category with the percentage of $8.43 \%$. (haryani: 2012). This means very high numbers of pornographic tendencies perpetrated by adolescents in the city of Padang.

The interview that the researcher did with BK teacher on March 1, 2017 at SMKN 2 Padang, found the indication of pornographic student. This can be seen from the existence of students who have read porn reading, never seen and do pornography, such as: holding hands with the opposite sex, and never save images or pornographic videos. This is done because students think it is a common thing, and students assume teenagers their age (15-18 years) should know about pornography itself.

The occurrence of pornographic tendencies in students is caused by a lack of information and understanding of students about how it should behave towards pornography itself.(haryani, dkk: 2012)

Based on the phenomenon that occurred above, the more asserted that the need for efforts of teachers BK / Counselor to develop the practice of Guidance and Counseling services to develop student potential so avoid the tendency of pornography. Efforts that can be done by teachers BK / Counselor for students have the right behavior against pornography is to utilize the services of Guidance and Counseling and supporting activities through various fields of development. One of the services that can be provided is layanan informasi.(Firman: 2009)

Layanan informasi are services that help learners receive, understand various personal information, social, learning, career, position, and further education. Information is needed and required in all aspects of human life. Someone will experience problems due to lack, absence and misinformation.(Winkel, dkk.: 2005, Dewa Ketut Sukardi: 2008, Ahmad: 2013,)

The goal to be achieved by the presentation of information is that the individual understand and accept themselves and their environment objectively, positively and dynamically, make decisions and direct themselves to useful activities in accordance with the decisions taken, and ultimately selfactualize in an integrated manner. Information received can be used as a reference attitude and behavior. (Prayitno:2004, Richma Hidayati: 2015)

Based on the results of further interviews with teachers of BK SMKN 2 Padang in March 2017, obtained information that teachers BK has provided layanan informasi to students, both in the form of classical and in the form of individuals, but teachers BK / Konselor not provide special layanan informasi related to how to students protected from pornography. Lessons learned by BK / Counselor teachers through layanan informasi can be modified with a variety of approaches. One approach that can be used in providing layanan informasi is the Contextual Teaching and Learning (CTL) approach.

CTL is a very effective learning approach that can make it easier for students to remember the material given by the teacher. CTL is a learning concept that helps teachers to relate between the material they are learning to the students' real-world situations and encourages students to make connections between their knowledge and their application in daily life involving seven effective components.(Nurhadi: 2009, Samriani)

CTL aims to enable students to be active in the learning process. CTL approach has advantages of learning becomes more meaningful for students, because learning takes place naturally in the form of work and experience students, rather than transfer knowledge from teacher to student and learning strategy is more important than the results. (Nurhadi:2009).

Through layanan informasi using CTL approach counselors can provide a variety of material services to students. layanan informasi materials tailored to the needs of students. One of the 
materials that can be provided through layanan informasi using the CTL approach is to recognize the impact of pornography. The provision of information services using the CTL approach will be able to shape student behavior so that it can avoid the tendency of pornography, because with the CTL approach the students are directed to link the material given to the real world life experienced, so that students will be able to easily practice the material that has been given in daily life -day(Prayitno :2004).

CTL has three basic principles, that is:: (1) learning to produce a relatively permanent change in the behavior of students, in this case the teacher is as a perpetrator of change, (2) students have the potential, the ability that is the natural seed to be grown without stopping, 3) change or achievement of the ideal quality does not grow naturally in the process of life (Johnson dalam Tukiran: 2014)

Observing the importance of behavior change to pornography, it is necessary to provide Guidance and Counseling service, in the form of information service using CTL approach. The information service is intended to provide information about what is needed by the students in fulfilling the need for actual data and information for the daily life of the individual.

Layanan informasi with problem solving method is effective in improving students' self control(Yana :2016Layanan informasi with effective role playing approach to improve students' social adjustment.(Fitri: 2016) Based on the results of the research, the layanan informasi is effective using any approach or learning method.

Based on the phenomenon in the field,BK Teachers already provide information services to students, but the provision of information services related to the prevention / reduction of pornographic tendencies has never been given, and in the provision of information materials provided by the teacher BK method using only the lecture method. Implementation of layanan informasi should use a variety of methods, techniques, and models of approaches or strategies that can help students to encourage an innovative and enjoyable learning process for students.

This indicates that in providing information services need to apply innovative and effective learning approach in helping solve student problems. One approach that can be used is the CTL approach.

Using the CTL approach, the implementation of information services can help BK teachers relate material provided to real-world situations, thus encouraging students to make connections between their knowledge and application in daily life, so as to change students' attitudes and behaviors towards the positive and avoid negative behavior. (M. Fauzi Hasibuan, Firman, Riska Ahmad: 2017)

Based on the results of research conducted Suryawatia, Osmanb, \& Meerahc (2010) shows that learning CTL successfully improve students 'skills in terms of problem solving skills and students' scientific attitude. Furthermore, Mardes (2016) research results show that information service using CTL approach is effective in improving students' self confidence in learning.

Based on the results of the above research, it can be concluded that the CTL approach is a learning system that matches the brain, which produces meaning by connecting the academic content to the context of the daily life of the students. Thus, information service using CTL approach is very well used in decreasing the tendency of student pornography.

Based on the phenomenon and the results of the research, the researcher is interested to conduct research using information service with CTL approach in decreasing the tendency of student pornography.

\section{Method}


His type of research is an experiment using descriptive quantitative approach using Quasi Experiment design through the design of The Non Equivalent Control Group. The population in this study is students of SMKN 2 Padang, because in this school there are problems studied by researchers. The samples in this study are the students of class XII TKJ 1 and XPL RPL students 1 . The reason the researcher chooses the class is based on the same class characteristics, the indicator to be studied is represented, collected from the observation done by the researcher, and the recommendation from the teacher BK / Counselor at the school. The research instrument uses a pornographic trend scale that has met the validity and reliability requirements $(0.892)$ of the research instrument. then analyzed using Wilcoxon Signed Rank Test and Kolmogorov Smirnov 2 Independent Samples.

\section{Result and Discussion}

The research data were obtained from members of experimental and control group with 42 members.

1. Pretest-Posttest Data Result

Based on data of pretest and posttest result of experiment group, we can see difference of student pornography tendency score in Table 3.

Table 3. Comparison of Student Pornography Trends Pretest-Posttest Experiment Group

\begin{tabular}{|c|c|c|c|c|}
\hline \multirow{2}{*}{$\begin{array}{l}\text { Student } \\
\text { code }\end{array}$} & \multicolumn{2}{|c|}{ Pretest } & \multicolumn{2}{|c|}{ Posttest } \\
\hline & Score & Category & Score & Category \\
\hline A 1 & 117 & Medium & 82 & Low \\
\hline A 2 & 95 & Medium & 55 & Very low \\
\hline A 3 & 66 & Low & 37 & Very low \\
\hline A 4 & 74 & Low & 52 & Very low \\
\hline A 5 & 100 & Medium & 65 & Low \\
\hline A 6 & 37 & Very low & 36 & Very low \\
\hline A 7 & 110 & Medium & 98 & Medium \\
\hline A 8 & 82 & Low & 69 & Low \\
\hline A 9 & 50 & Very low & 47 & Very low \\
\hline A 10 & 82 & Low & 54 & Very low \\
\hline A 11 & 112 & Medium & 94 & Medium \\
\hline A 12 & 95 & Medium & 62 & Very low \\
\hline A 13 & 77 & Low & 55 & Very low \\
\hline A 14 & 63 & Low & 63 & Low \\
\hline A 15 & 48 & Very low & 44 & Very low \\
\hline A 16 & 67 & Low & 61 & Very low \\
\hline A 17 & 73 & Low & 42 & Very low \\
\hline A 18 & 73 & Low & 70 & Low \\
\hline A 19 & 148 & Very high & 122 & high \\
\hline A 20 & 53 & Very low & 39 & Very low \\
\hline A 21 & 108 & Medium & 94 & Medium \\
\hline Average & 82,38 & Low & 63,86 & Low \\
\hline
\end{tabular}

Based on Table 3, it can be concluded that the experimental group experienced a decrease in the pornographic trend score after being given information service using CTL approach. Before the information service was provided using the CTL approach, the average pretest score was 82.38 and 
was in the low category. Furthermore, after being given information service using CTL approach the mean of posttest score decrease to equal to 63,86 which is in low category.

Comparison of experimental groups from pretest and posttest results on pornographic trends can be seen in Table 4.

Table 4. Frequency comparison of pornographic tendencies of the Pretest-Posttest Experiment GroupGroup

\begin{tabular}{|c|c|c|c|c|c|}
\hline \multirow[t]{2}{*}{ Interval } & \multirow[t]{2}{*}{ Category } & \multicolumn{4}{|c|}{ Frequency } \\
\hline & & Pretest & $\%$ & Posttest & $\%$ \\
\hline$\geq 147$ & Very High & 1 & 4,76 & 0 & 0 \\
\hline $119-146$ & High & 0 & 0 & 1 & 4,76 \\
\hline $91-118$ & Medium & 7 & 33,33 & 3 & 14,29 \\
\hline $63-90$ & low & 9 & 42,86 & 5 & 23,81 \\
\hline$\leq 62$ & Very low & 4 & 19,05 & 12 & 57,14 \\
\hline & & 21 & 100 & 21 & 100 \\
\hline
\end{tabular}

Based on Table 4, it can be seen that there are differences in the tendency of student pornography in the experimental group before and after following the information service using CTL approach. The tendency of student pornography at the time of pretest is in very high category as much as 1 student with percentage $4,76 \%$, in medium category as many as 7 students with percentage $33,33 \%$, in low category counted 9 student with percentage $42,86 \%$, at category very low 4 students with percentage $19.05 \%$, After being given information service using CTL approach of change, which can be seen from posttest result as much as 1 student is in high category with percentage $4,76 \%$. In the medium category as many as 3 students with percentage of $14.29 \%$, in the low category as many as 5 students with $23.81 \%$ percentage, and 12 students are in very low category with the percentage of $57.14 \%$.

Furthermore, the results of research data obtained in the control group, based on instruments that have been given to 21 students before and after given information services. The following shows the score of each student pornography tendency in the control group before and after given information service using lecture method.

Table 5. Comparison of Pretest-Posttest Score of Control Group

\begin{tabular}{ccccc}
\hline Kode Siswa & \multicolumn{2}{c}{ Pretest } & \multicolumn{2}{c}{ Posttest } \\
\cline { 2 - 5 } & Skor & Kategori & Skor & Kategori \\
B 1 & 89 & Low & 67 & Low \\
B 2 & 112 & Medium & 88 & Low \\
B 3 & 40 & Very Low & 38 & Very Low \\
B 4 & 103 & Medium & 86 & Low \\
B 5 & 57 & Very Low & 55 & Very Low \\
\hline
\end{tabular}




\begin{tabular}{ccccc}
\hline B $\mathbf{6}$ & 70 & Low & 66 & Low \\
B 7 & 94 & Medium & 72 & Low \\
B 8 & 64 & Low & 60 & Very Low \\
B 9 & 125 & Tinggi & 116 & Medium \\
B 10 & 65 & Low & 43 & Very Low \\
B 11 & 56 & Very Low & 55 & Very Low \\
B 12 & 100 & Medium & 94 & Medium \\
B 13 & 46 & Very Low & 45 & Very Low \\
B 14 & 56 & Very Low & 47 & Very Low \\
B 15 & 92 & Medium & 92 & Medium \\
B16 & 123 & High & 107 & Medium \\
B 17 & 74 & low & 63 & Low \\
B 18 & 62 & Very Low & 46 & Very Low \\
B 19 & 83 & Low & 64 & Low \\
B 20 & 117 & Medium & 108 & Medium \\
B 21 & 105 & Medium & 67 & Low \\
Rata-rata & $\mathbf{8 2 , 5 2}$ & Low & $\mathbf{7 0 , 4 2}$ & Low \\
\hline
\end{tabular}

Based on Table 5, it can be seen that the tendency of student pornography in the control group decreased after being given information service using lecture method. Before the information service was provided using the lecture method, the average pretest score was 82.52 and was in the low category. Furthermore, after being given information services using the lecture method, the average posttest score decreased to 70.42 was in the low category.

The frequency distribution of the control group condition from pretest to posttest results on the trend of student pornography can be seen in the Table 6 .

Based on Table 6, it can be seen that there are differences in the tendency of student pornography in the control group before and after following the information service using the lecture method. The tendency of student pornography at the time of pretest is in high category as much as 2 students with percentage $9,53 \%$, in medium category as many as 7 students with percentage $33,33 \%$, in low category counted 6 student with percentage $28,57 \%$, at very low category as many as 6 students with percentage $28,57 \%$. After given information service change, which can be seen from posttest result as much as 5 student is in medium category with percentage $23,80 \%, 8$ student is in low category with percentage $38,10 \%$, and 8 student is in very low category with percentage $38.10 \%$.

Table 6. Pretest and Posttest Outcomes of Pornographic Trends in Student Group Control

\begin{tabular}{cccccc}
\hline Interval & Kategori & \multicolumn{4}{c}{ Frekuensi } \\
\cline { 3 - 5 } & & Pretest & $\%$ & Posttest & $\%$ \\
\multirow{2}{*}{$\geq \mathbf{1 4 7}$} & Sangat Tinggi (ST) & 0 & 0 & 0 & 0 \\
$\mathbf{1 1 9 - 1 4 6}$ & Tinggi (T) & 2 & 9,53 & 0 & 0 \\
\hline
\end{tabular}




\begin{tabular}{cccccc}
\hline $\mathbf{9 1 - 1 1 8}$ & Sedang (KT) & 7 & 33,33 & 5 & 23,80 \\
$\mathbf{6 3 - 9 0}$ & Rendah (R) & 6 & 28,57 & 8 & 38,10 \\
$\mathbf{3 6 2}$ & Sangat Rendah (SR) & 6 & 28,57 & 8 & 38,10 \\
& Jumlah & 21 & 21 & 21 & 21 \\
\hline
\end{tabular}

The finding of this research is information service using CTL more effective in decreasing tendency of student pornography. Furthermore, to further comprehend conceptually the results of this study, then conducted a discussion of the results of research as follows:

\section{Picture of Student Pornography Trend}

The results showed that at the time of pretest condition of student pornography in class XII TKJ 1 and XII RPL 1 SMKN 2 Padang are in the category of equally low. After being given treatment by providing information service using CTL approach in the experiment group decreased with the average was in the low category, and information service using lecture method to the control group also decreased, was in low category, but decreased tendency of pornography of lower students in the experimental group who were given information services using CTL approach.

\section{Differences in Student Pornographic Trends in Experimental Groups Before and After Following Information Services Using CTL Approach.}

Based on the results of the first hypothesis testing that reads "There is a significant difference in the tendency of student pornography in the experimental group before and after given information service using CTL approach".

From the pretest results it is known that the experimental group has a tendency of pornography that is in the low category, but so on the subject of this study there are indeed students who behave pornography. Therefore, the researcher gives treatment in the form of information service using CTL approach in the experimental group to decrease the tendency of student pornography. After given pretest and posttest and hypothesis tested then got result that "there is significant difference". This means that, after being given information services using CTL approach, there is a decrease in the tendency of student pornography.

Pornography can be prevented or can be reduced through information services using the CTL approach. This can be seen from the results of the average score of the experimental group that experienced a decrease in scores.

This is in line with the results of Suryawatia, Osmanb, \& Meerahc (2010) research indicating that CTL is successful and significant to improve students 'skills in terms of problem solving skills and students' scientific attitudes. CTL can improve students' critical thinking skills and train them to be more different and evaluative than learning lecture methods.

Through information services using the CTL approach, students become very enthusiastic and actively participate in the discussion, so that with this activity, many students get new things that can be utilized in everyday life. A pure learning process occurs naturally where the thinking process of the student is able to construct or construct his own information or knowledge in such a way that the knowledge becomes meaningful in accordance with the material context discussed. It is seen in the process of observation that researchers do, the students are able to mengkontruksi their minds so that students are able to understand that pornography is very bad and not good for yourself and others.

Through information services using the CTL approach, students are directed to construct their knowledge gradually to build meaningful understanding through real experience. Students are 
enthusiastic and start daring to express opinions, students are able to appreciate the opinions of others, as well as students begin to have an interest to know the information discussed.

A class is said to use CTL when applying the seven components present in CTL. To do that is not difficult, the implementation of information services using CTL is given in a classical format. The material given is by executing the seven components of CTL well. CTL is a learning concept that helps teachers connect between material taught to the real-world situations of students and encourages students to make connections between their knowledge and application in everyday life.

Based on the results of research conducted by researchers, it can be understood that, to reduce the tendency of student pornography is very effective by providing information services using CTL approach. The provision of information services using CTL approach can significantly decrease the student pornography tendency score.

\section{Differences in Pornographic Trends in Student Group Controls Before and After Following Information Services Using Lecture Methods.}

Based on the results of the second hypothesis testing which reads "There is a significant difference of pornography tendency of control group students before and after given information service using lecture method", it can be seen that, information service by using lecture method make decreasing of pornography tendency score of student, is not as significant in the experimental group. The results showed that, there was a decrease in the pornographic trend score of students in the control group. This can be seen from the comparison between pretest results and posttest results. In the pretest results the control group had an average score of 82.52. At the time of posttest the student pornography tendency scores fell to 74.52. Thus, it can be seen that in the control group who followed the information service using the lecture method decreased the score of pornographic tendencies.

\section{Differences in Pornographic Trend of Students of Experiment Group and Control Group After Following Service.}

In the experimental and control groups both experienced a decrease in scores after service delivery, however, the decrease in scores was higher in the experimental group. The provision of information services using lecture methods in the control group is also well done, but the implementation process makes the driving force available to students not working optimally. This can be seen from the observations seen in the students, who just sit back and listen to what the teacher explains. Students are not enthusiastic / less active in following the services provided by the teacher. This is because information services using lecture methods only provide science to students, students are more silent listening to material given teachers. There is no student activity in the learning process, and the interaction between teachers and students in PBM only one direction only.

Based on the posttest results in the control group, information services using lecture methods were also effective in decreasing the tendency of student pornography, but the decrease in scores was not as significant in the experimental group using information service with CTL approach. The results showed that information service using CTL approach was more effective than control group given information service using lecture method.

This is due to the components in CTL which become an advantage on the learning approach, thus making students more active in the learning process. CTL is a learning concept that helps teachers connect between material taught to students with real-world situations. Seen during the learning process takes place in the classroom, such as the disclosure of the students' initial knowledge about the subject matter. Students are able to construct their thoughts, so that students can express their experiences, knowledge discovery about the given material, ask questions become more active, creative and compact group work, volunteer students give examples as model of learning, students are able to reflect on the material given, an authentic assessment capable of revealing changes in student pornography. Students are more active, passionate and creative in the learning process. In the 
information service using the lecture method that the learning process looks monotonous, making the students are not active in asking and responding when the teacher explains the material, the students look less excited and there is saturation in students.

Based on the results of this research, BK teachers / counselors should be more creative in providing services Guidance and Counseling, especially in providing information services. Thus, the use of an approach in the delivery of information services makes its implementation easier, more creative, and fun. Based on the data analysis above, it can be concluded that information service with lecture method is also good to be implemented, as long as the stages are good, but the information service using CTL is more effective in decreasing the tendency of student pornography.

\section{Conclusion}

Based on the research findings obtained after performing statistical analysis and hypothesis testing, it can be concluded in general that "information service using CTL approach is more effective in reducing the tendency of student pornography". Specifically, the findings of this study are as follows:

1. There is a significant difference in the pornographic trend of students before and after following information services using the CTL approach.

2. There is a significant difference in the pornographic trend of students before and after following information services using lecture methods.

3. Information service using CTL approach is more effective in reducing the tendency of student pornography than information service using lecture method.

\section{Acknowledgment}

Researchers realize that the success of preparing this journal can not be separated from the help of various parties, both morally and materially, for that the researchers say a sincere gratitude to:

1. Prof. Mr. Dr. Firman, M.S., Kons., As mentor I, and Mrs. Prof. Dr. Nurhizrah Gistituati, M.Ed., Ed.D., as a caring supervisor II has guided and directed the writer with great patience, wisdom and sincerity that is tireless in the midst of his busy life. Always provide motivation so that researchers can complete this journal.

2. Mrs. Dr. Syahniar, M.Pd., Kons., As the first contributor, Mr. Daharnis, M.Pd., Kons., As the second contributor, Mrs. Dr.Yarmis, M.Pd, Kons., As the third contributor, who has provided very meaningful input in improving the preparation of this journal.

3. Mr. and Mrs. Lecturer PPs FIP UNP, especially Lecturer Guidance and Counseling Department which has provided various science knowledge so very helpful in completing this journal. 


\section{References}

Ahmad, R. (2013). Dasar-dasar Bimbingan dan Konseling. Padang: UNP Press.

Bungin. (2007). Sosiologi Komunikasi. Jakarta: Kencana Predana Media Group.

Desneli, Firman, dan Afrizal Sano. (2016). Peningkatan Penyesuaian Diri Siswa Melalui Layanan Informasi. Konselor. 2 (2).

Firman. (2009). Tanggung Jawab Profesi Guru dalam Era Teknologi Informasi. Konselor. IX (1),

Fitri, Y. A. (2016). “Efektivitas Layanan Informasi dengan Pendekatan Role Playing untuk Meningkatkan Penyesuaian Sosial Siswa. Tesis tidak diterbitkan. Padang: Prodi S2 BK FIP UNP.

Haryani. (2012). Dampak Pornografi terhadap Perilaku Siswa dan Upaya Guru Pembimbing untuk Mengatasinya. Konselor. 1 (1)

Imalatul Khaira, Firman, Neviyarni S. (2017).Efektivitas Pendekatan Rational Emotive Behavior Therapy (Rebt) Dalam Meningkatkan Penyesuaian Sosial Anak Asuh Di Panti Asuhan Wira Lisna Padang. Konselor. 1 (1).

Katarina Leba dan Murni Hermawaty Sitanggang. (2015). Pentingnya Peningkatan Religiositas untuk Mengatasi Pornografi dikalangan Orang Muda Kristen. 4 (1). CARI DI JURNAL MANA DI AMBIL

Komisi Perlindungan Anak Indonesia. (2016). Tabulasi Data Kasus Anak. (Online) KPAI.go.id. diakses pada tanggal 27 Februari 2017.

Mardes, S. (2016). Efektivitas Layanan Informasi dengan Pendekatan Contextual Teaching And Learning untuk MeningkatkanKepercayaan Diri Siswa dalam Belajar. Tesis tidak diterbitkan. Padang: Program Pasca Sarjana Bimbingan Konseling UNP.

M. Fauzi Hasibuan, Firman, Riska Ahmad. (2016). Efektivitas Layanan Informasi Dengan Menggunakan Pendekatan Contextual Teaching And Learning Dalam Mengurangi Sikap Siswa Terhadap Gaya Hidup Hedonisme. Tesis.tidak diterbitkan. Padang: Program Pasca Sarjana Bimbingan Konseling UNP.

Nory Natalia, Firman \& Daharnis. (2015). Efektivitas Layanan Informasi dengan Menggunakan Media Audio Visual dalam Meningkatkan Sikap Siswa terhadap Kedisiplinan Sekolah. Konselor. 3 (2).

Nurhadi. (2009). Model Pembelajaran. Surabaya: Jepe Press Media Utama

Prayitno. (2004). Dasar-dasar BK. Jakarta: Rineka Cipta.

Richma Hidayati. (2015). Layanan Informasi Karier Membantu Peserta Didik Dalam Meningkatkan Pemahaman Karier. Konselor.1, (1).

Samriani. Tanpa tahun. Penerapan Pendekatan Contextual Teaching And Learning (CTL) Dalam Meningkatkan Hasil Belajar Siswa Pada Mata Pelajaran IPA di Kelas IV SDN No 3 Siwalempu.(Online) Vol. 4 No. 2 ISSN 2354-614X. diakses tanggal 24 Januari 2018.

Sartika. Dinas P3AKB. (2016). Dampak Mengerikan serta Solusi bagi Pecandu Pornografi. Bandung: Badan Pemberdayaan Perempuan Perlindungan Anak dan Keluarga Berencana 
Sarwono. (2005). Psikologi Remaja. Jakarta: Raja Grafindo Persada.

Sri Sunarsih. (2010). Hubungan Frekuensi Paparan Media Pornografi dengan Frekuensi Masturbasi Remaja Putra di SMK Wongsorejo Gombong Kebumen. (Online), Vol. 1, No. 1, diakses tanggal 23 Januari 2018.

Suryawatia, E., Osmanb, K., \& Meerahc, T. S. M. (2010). The effectiveness of RANGKA contextual teaching and learning on students' problem solving skills and scientific attitude. Journal Social and Behavioral Sciences, DOI:10.1016/j.sbspro.2010.12.389, 1877-0428 @ 2010 Published by Elsevier Ltd. Faculty of Education, Universiti Kebangsaan Malaysia. (Online), Vol. 12, No. 389:17171721,(http://www.sciencedirect.com/, diakses pada tanggal 25 Desember 2016)

Tukiran. (2014). Model-Model Pembelajaran Inovatif dan Efektif. Bandung: Alfabeta.

Winkel dkk. (2005). Bimbingan dan Konseling di institusi Pendidikan. Yogyakarta: Media Abad

Yana, R. F. (2016). “Efektivitas Layanan Informasi dengan Metode Problem Solving terhadap Peningkatan Kontrol Diri Siswa". Tesis tidak diterbitkan. Padang: Prodi S2 BK FIP UNP.

Yulianto. (2010). Gambaran Sikap Siswa SMP Terhadap Perilaku Seksual Pranikah. (Online), Vol. 8, No. 2, diakses tanggal 16 Maret 2017. 